\title{
Behavior of red cell distribution width (RDW) in a population of anemic and non-anemic dogs from an ambulatory care unit*
}

\section{Comportamento do índice de anisocitose (RDW) em uma população de cães anêmicos e não anêmicos de uma unidade de atendimento ambulatorial}

\author{
Aline Moreira de Souza, ${ }^{* \star}$ Joylson de Jesus Pereira, ${ }^{* *}$ Sabrina Destri Emmerick Campos, ${ }^{* *}$ Daniela Tendler Leibel Bacellar, ${ }^{* * *}$ \\ Rodolpho Almeida Torres Filho, ${ }^{* * *}$ Daniel de Barros Macieira, ${ }^{* *}$ Nádia Regina Pereira Almosny ${ }^{* *}$
}

\begin{abstract}
Resumo
O objetivo deste estudo foi avaliar o comportamento do índice de anisocitose na interpretação do hemograma de cães anêmicos e não anêmicos. Atualmente, contadores hematológicos automatizados veterinários fornecem alguns índices que não são calculados quando o hemograma é confeccionado manualmente. A saber: RDW-CV (Amplitude de distribuição de hemácias como coeficiente de variação) e RDW-SD (Amplitude de distribuição de hemácias como desvio-padrão). Tais índices levaram a uma nova abordagem do paciente com anemia permitindo que a anisocitose fosse mensurada de uma forma quantitativa. Foram avaliados 454 hemogramas processados no período de setembro de 2009 a março de 2011. Foram calculados média e desvio padrão e uma análise de variância foi realizada. Os cães anêmicos (125/454) apresentaram altos valores de RDW enquanto que, em animais não anêmicos, esse índice permaneceu dentro dos valores de normalidade previamente estabelecidos. $O$ índice também estava alto em animais com anisocitose observada à microscopia. Houve uma diferença significante entre os índices dos animais que apresentaram Volume Globular Médio (VGM) elevado e normal. Concluiu-se que os índices RDW-CV e RDW-SD foram sensíveis a pequenas variações no tamanho das hemácias e na heterogeneidade, sendo mais precisos que a observação microscópica para se detectar anisocitose e mais sensível que VGM para variação eritrocitária.
\end{abstract}

Palavras-chave: anemia, anisocitose, contador hematológico automatizado, hematologia.

\begin{abstract}
The aim of this study was to evaluate the behavior of the red cell distribution width (RDW) in the interpretation of the Complete Blood Count (CBC) from anemic and non-anemic dogs. Currently, automated veterinary blood cell analyzers provide hematologic indices not calculated in manually performed CBC, such as Red Blood Cell Distribution Width measured by Variation Coefficients (RDW-CV) and Red Blood Cell Distribution Width measured by Standard Deviation (RDW-SD), which has led to new of September 2009 to March 2011. Mean and standard deviation were calculated and variance analysis was performed. Anemic dogs (125/454) presented higher values for RDW indices. In non-anemic animals, these indices were in accordance with the normal values previously established. Both indices were higher in dogs with microscopic observation of anisocytosis. There was a significant difference among índices of the animals which showed normal and increased Mean Corpuscular Volume (MCV). We concluded that RDW-CV and RDW-SD indices were sensitive to small variations on erythrocyte size and heterogeneity, being more accurate than microscopic observations to detect anisocytosis and more sensitive than MCV to erythrocyte variation.
\end{abstract}

Keywords: anemia, anisocytosis, automated cell analyzers, hematology

\section{Introduction}

Complete blood counts (CBC) provide to veterinarians a wide range of information about an animal's health. Nowadays automated blood cell analyzers are available, providing other hematologic indices not calculated in manually performed CBCs, such as Red Blood Cell Distribution Width measured by Variation Coefficient (RDW-CV) and Red Blood Cell Distribution Width measured by Standard Deviation (RDW-SD), which has led to new approaches to patients with anemia (Balarin et al., 2001; Žvorc et al., 2010; Temizel et al., 2011; Souza et al., 2012).

Reticulocyte count, Mean Corpuscular Volume (MCV) and Mean Corpuscular Hemoglobin Concentration (MCHC) are still widely used as standard parameters for anemia classification, in accordance with the animal's bone marrow response (Weiss e Townsend, 1998; Neiger et al., 2002; Žvorc et al., 2010). However, too many erythrocytes with modified volumes are

\footnotetext{
*Recebido em 18 de outubro de 2015 e aceito em 28 de março de 2017.

** Universidade Federal Fluminense, Faculdade de Veterinária, Departamento de Patologia e Clínica Veterinária, Niterói, RJ, Brasil.

${ }^{* * *}$ Fundação Oswaldo Cruz; Instituto Nacional de Controle de Qualidade em Saúde, Rio de Janeiro, RJ, Brasil.

****Universidade Federal Fluminense, Faculdade de Veterinária, Departamento de Zootecnia, Niterói, RJ, Brasil.

Autor para correspondência: alinems@id.uff.br
} 
necessary to affect the MCV whereas RDW is sensitive to small variations on the erythrocyte's size (Simel et a1., 1988; Neiger et al., 2002; Žvorc et al., 2010).

RDW indices evaluate the heterogeneity of red blood cells providing a quantitative measure of anisocytosis (Neiger et al., 2002). Automated cell analyzers show the distribution of erythrocyte volume in $95 \%$ of the blood sample and determine its coefficient of variation (RDW-CV), which is calculated from an equation. This index is related to the MCV and it is expressed in percentage (Balarin et al., 2001; Monzon et al., 2006). The RDW-SD is the standard deviation of the erythrocyte distribution curve, expressed in fentoliter ( $\mathrm{fL}$ ), being a direct measure, which is independent of MCV and so accurately demonstrates the variation in size of an erythrocyte population (Walters, 2002).

Increased RDW values indicate a heterogeneous population of red blood cells and normal values indicate a homogeneous population (Brollo e Tavares, 2010). In dogs, increased RDW-CV and RDW-SD values occur in regenerative anemia (hemolysis or hemorrhage) or in ineffective red cell production, such as iron, B12 or folate deficiency and hemoglobinopathies, before the elevation of MCV, being a premature pointer of anisocytosis (Žvorc et al., 2010; Temizel et al., 2011; Souza et al., 2012).

So, the aim of this study was to evaluate the behavior of Red Blood Cell Distribution Width indices (RDW-CV and RDW-SD) in the interpretation of Complete Blood Counts in anemic and non-anemic dogs.

\section{Materials and methods}

This study was approved by the Ethics Committee on Animal Research of the Universidade Federal Fluminense (CEUA-UFF), under number 00157/09.

To perform this study, CBC results of 454 dogs from the $X X X$, were reviewed.

CBCs were performed in an automated veterinary hematology counter Sysmex® - Poch 100 IV DIFF from September 2009 to March 2011.

Anemia was considered when packed cell volume $(\mathrm{PCV})<37 \%$, and based on these results dogs were grouped as anemic and non-anemic animals. Blood smears were stained by quick staining (Panótico Instant Prov $\left.{ }^{\circledR}\right)$ and evaluated under 1000x magnification to confirm the results of the hematology counter and to search for abnormalities.
Descriptive statistics was performed in order to evaluate the assumptions of analysis of variance (F-test). There was the need to transform variables by the log-transformation (base 10). The effect of anemia on RDW indices was evaluated using variance analyses (ANOVA), and expressed as Mean \pm Standard Deviation (SD). Pearson's correlation coefficient was used to test associations between variables. Results were considered significant when $\mathrm{p}<0.05$.

\section{Results and discussion}

The blood samples analyzed consisted of 125 anemic dogs (PCV $<37 \%$ ) and 329 dogs with $\mathrm{PCV}$ within the normal range $(37 \% \leq \mathrm{PCV} \leq 55 \%)$. Mean and SD of RDW-CV and RDW-SD erythrocyte indices in anemic and non-anemic dogs processed in the Sysmex® - Poch 100 iv analyzer are shown in Table 1.

Table 1: Mean values and standard deviation (SD) for Red Blood Cell Distribution Width indices, RDW-CV (\%) and RDW-SD (fL), in blood samples of anemic and non-anemic dogs, processed in Automated Veterinary Hematology Counter Sysmex® Poch 100iv

\begin{tabular}{llll}
\hline Dogs & $\mathrm{N}$ & $\mathrm{RDW}-\mathrm{SD}(\mathrm{fL})^{\mathrm{b}}$ & $\mathrm{RDW}-\mathrm{CV}(\%)^{\mathrm{c}}$ \\
\hline Anemic $\left(\mathrm{PCV}^{\mathrm{a}}<37 \%\right)$ & 125 & $37.698 \pm 6.16^{\mathrm{A}}$ & $13.87 \pm 6.168^{\mathrm{A}}$ \\
Non-anemic $\left(37 \% \leq \mathrm{PCV}^{\mathrm{a}} \leq 55 \%\right)$ & 329 & $27.271 \pm 11.319^{\mathrm{B}}$ & $11.171 \pm 1.882^{\mathrm{B}}$ \\
\hline Total & 454 & $30.191 \pm 11.168$ & $11.928 \pm 2.605$ \\
\hline
\end{tabular}

apacked cell volume, ${ }^{\mathrm{b}}$ Red Blood Cell Distribution Width Standard Deviation, ${ }^{\mathrm{C}}$ Red Blood Cell Distribution Width Variation Coefficients

Means followed by different letters (A or B) differed at a $5 \%$ significance.

Few observations of anisocytosis in the blood smear analyses were noticed in this study. Only in $79 / 454$ CBCs $(17.4 \%)$ was anisocytosis observed. From these, 36/79 (45.6\%) were anemic dogs. ANOVA analysis was also performed for RDW-CV and RDW-SD in these 79 dogs and the results were considered significant $(p<0.05)$, which may be seen in Table 2:

Table 2: Mean values, standard deviation (SD) for Red Blood Cell Distribution Width indices, RDW-CV (\%) and RDW-SD (fL), in blood samples of 79 anemic and non-anemic dogs, processed in Automated Veterinary Hematology Counter Sysmex® Poch 100iv, in which veterinarian have perceived anisocytosis in blood smears

\begin{tabular}{llll}
\hline Dogs & $\mathrm{N}$ & RDW-SD $(\mathrm{fL})^{\mathrm{b}}$ & ${\text { RDW-CV }(\%)^{\mathrm{c}}}^{\circ}$ \\
\hline Anemic $\left(\mathrm{PCV}^{\mathrm{a}}<37 \%\right)$ & 36 & $42.456 \pm 8.726^{\mathrm{A}}$ & $16.208 \pm 3.856^{\mathrm{A}}$ \\
Non-anemic $\left(37 \% \leq \mathrm{PCV}^{\mathrm{a}} \leq 55 \%\right)$ & 43 & $30.654 \pm 9.967^{\mathrm{B}}$ & $11.202 \pm 1.258^{\mathrm{B}}$ \\
\hline Total & 79 & $36.031 \pm 11.074$ & $13.483 \pm 3.717$ \\
\hline
\end{tabular}

apacked cell volume, ${ }^{\mathrm{b}}$ Red Blood Cell Distribution Width Standard Deviation, ${ }^{\mathrm{C}}$ Red Blood Cell Distribution Width Variation Coefficients

Means followed by different letters (A or B) differed at a $5 \%$ significance. 
Table 3 reported that there was a significant difference $(p<0.05)$ for RDW-SD and RDW-CV among animals showing normal MCV $(60-77 \mathrm{fL})$ and animals that showed increased MCV (>77fL).

Table 3: Mean values and standard deviation (SD) for Red Blood Cell Distribution Width indices, RDW-CV (\%) and RDW-SD (fL), in blood samples of 125 anemic dogs, processed in Automated Veterinary Hematology Counter Sysmex ${ }^{\circledR}$ Poch 100iv, according to the distribution of Mean Corpuscular Volume (MCV) range values

\begin{tabular}{|c|c|c|c|}
\hline$M C V^{a}$ range values (fL) & $\mathrm{N}$ & RDW-SD (fL) $)^{b}$ & RDW-CV $(\%)^{c}$ \\
\hline$<60$ & 17 & $38.876 \pm 7.381^{\mathrm{B}}$ & $16.317 \pm 3.692^{\mathrm{B}}$ \\
\hline $60-62$ & 8 & $34.862 \pm 1.919^{\mathrm{B}}$ & $13.050 \pm 1.215^{\mathrm{C}, \mathrm{D}}$ \\
\hline $62.1-65$ & 23 & $35.008 \pm 3.164^{\mathrm{B}}$ & $12.665 \pm 1.847^{\mathrm{C}, \mathrm{D}}$ \\
\hline $65.1-68$ & 26 & $35.100 \pm 2.235^{\mathrm{B}}$ & $12.161 \pm 1.370^{\mathrm{D}}$ \\
\hline $68.1-71$ & 30 & $37.253 \pm 4.662^{\mathrm{B}}$ & $13.143 \pm 2.330^{\mathrm{C}, \mathrm{D}}$ \\
\hline $71.1-74$ & 13 & $40.753 \pm 6.274^{\mathrm{B}}$ & $14.676 \pm 3.364^{\mathrm{B}, \mathrm{C}, \mathrm{D}}$ \\
\hline $74.1-77$ & 4 & $41.300 \pm 7.196^{\mathrm{B}}$ & $15.800 \pm 3.373^{\mathrm{B}, \mathrm{C}}$ \\
\hline$>77$ & 4 & $56.000 \pm 9.239^{A}$ & $21.125 \pm 4.643^{\mathrm{A}}$ \\
\hline Total & 125 & $37.553 \pm 6.158$ & $13.776 \pm 3.120$ \\
\hline
\end{tabular}

aMean Corpuscular Volume, ${ }^{b}$ Red Blood Cell Distribution Width Standard Deviation, ${ }^{\circ}$ Red Blood Cell Distribution Width Variation Coefficients

Means followed by different letters (A, B, C or D) differed at a $5 \%$ significance.

When comparing groups by ANOVA, we have observed that anemic dogs presented higher values for RDW-CV and RDWSD than non-anemic dogs. Still, the averages for RDW-CV and RDW-SD in non-anemic animals were in accordance with the normal values previously proposed (Souza et al., 2012).

In human beings, RDW indices can be used to evaluate bone marrow response and to classify the types of anemia (Bessman et al., 1983; Perret et al., 2001). In anemic dogs, elevated values of RDW-CV and RDW-SD indicate heterogeneity in the size of erythrocytes (Brollo e Tavares, 2010), which could indicate the presence of macrocytic erythrocytes and bone marrow response or microcytic erythrocytes, which is more probable in microcytic anemia.

In the case of regenerative anemia, such as bleeding or hemolysis, young erythrocytes are released into the circulation, resulting in anisocytosis and increase of RDW indices (Žvorc et al., 2010). However, RDW indices also increase when erythrocytes production is inefficient as in iron, B12 and folate deficiency or hemoglobinopathies, erythrocyte destruction and after blood transfusion (Žvorc et al., 2010; Temizel et al., 2011). In regenerative anemia, RDW is most commonly increased during the phase in which there is a significant number of erythrocytes with normal and abnormal sizes simultaneously (Žvorc et al., 2010).

In cases where there was microscopic observation of anisocytosis, anemic dogs also had a higher RDW index, which agrees with authors who consider the microscopic evaluation of cell morphology a subjective method because it is based on a visual inspection and it can suffer variation among laboratories (Roberts e El Badawi, 1985; Failace, 2009).

The significant difference $(p<0.05)$ for RDW-SD and RDW-CV among animals showing normal MCV (60-77fL) and animals that showed increased MCV (>77fL) may indicate that, in anemic dogs, both the MCV and RDW were sensitive to variations in the size of erythrocytes. A study on the regenerative and non-regenerative anemia in dogs also observed similar results (Neiger et al., 2002).

The normocytic anemia expressed lower RDW-SD and RDW-CV than the anemia that progressed with MCV $>77 \mathrm{fL}$ and RDW-CV were statistically different in dogs with diminished MCV $(<60 \mathrm{fL})$ when compared to those with normal MCV (60-77fL). Both cases were in agreement with a study that has demonstrated that RDWCV increases in microcytic anemia and RDW-SD increases in macrocytic anemia (Brollo e Tavares, 2010).

Animals with MCV from 71,1fL to $77 \mathrm{fL}$ have obtained higher RDWSD and RDW-CV values than the normal range established (Souza et al., 2012). This could indicate a tendency to macrocytosis even before the increase of MCV, considering that this index can perceive smaller variations in erythrocyte size whereas MCV needs a larger number of cells with anisocytosis to rise.

We also note that animals with $\mathrm{MCV}<62 \mathrm{fL}$ have obtained higher RDW-CV values than the normal values. This finding may indicate microcytic erythrocytes before the decrease of $\mathrm{MCV}$. Although it has not been found yet in studies supporting this correlation in dogs, it is known that human patients with low MCV but high RDW often have iron deficiency or red blood cell fragmentation (Monzon et al., 2006).

\section{Conclusion}

Based on the results, it was possible to observe the behavior of RDW in anemic and non-anemic dogs. We concluded that anemic dogs presented higher values for RDW-CV and RDW-SD than non-anemic dogs. Also, RDW indices were more accurate than microscopic observations to detect anisocytosis. And the indices were more sensitive than MCV to detect erythrocyte size variation.

\section{Acknowledgements}

To CNPq, FAPERJ and Proppi/UFF for financial support and scholarship and to Controllab® for quality control. 


\section{References}

BALARIN, M.R.S.; FONTEQUE, J.H.; SOUZA, C.; SAITO, M.E.; Kohayagawa, A.; Lopes, R.S. Valores da amplitude de distribuição do tamanho dos eritrócitos (RDW-Red Cell Distribution Width) em quinos da raça Puro Sangue Inglês (PSI) de ambos os sexos de 12 a 24 meses de idade. Semina: Ci Agr, v. 22, p.135-137, 2001.

BESSMAN, D.J.; GILMER, P.R.; GARDNER, F.H. Improved classification of anemias by MCV and RDW. Am. J. Clin. Pathol; v. 80, n. 3, p. 322-326, 1983.

BROLLO, C.; TAVARES, R.G. Avaliação Comparativa dos Parâmetros Hematológicos RDW-CV e RDW-SD. NewLab 2010; v. 103, p.164-168.

FAILACE, R. Hemograma: manual de interpretação. 5th edn. Artmed, Porto Alegre, 2009.

MONZON, C.M.; BEAVER, B.D.; DILLON, T.D. Evaluation of erythrocyte disorders with mean corpuscular volume (MCV) and red cell distribution width (RDW). Clin Pediatr 2006; v. 26, n. 12, p. 632-638.

NEIGER, R.; HADLEY, J.; PFEIFFER, D.U. Differentiation of dogs with regenerative and non-regenerative anemia on the basis of their red cell distribution width and mean corpuscular volume. Vet Rec; v. 6, p. 43-44, 2002.

PERRET, D.; TRUMEL, C.; DIQUELOU, A.; DOSSIN, O.; GULEFI, J.F. L'indice de distribution des globuler rouges (IDR) chez le chien. Analyse de 1400 cas. Revue Méd Vét 2001; v. 152, p. 549-554.
ROBERTS, G.T.; EL BADAWI, S.B. Red cell distribution width index in some hematologic diseases. Am J Clin Pathol 1985; v. 83, p. 222-226.

SIMEL, D.L.; DELONG, E.R.; FEUSSNER, J.R.; WEINBERG, J.B.; CRAWFORD, J. Erythrocyte Anisocytosis: Visual Inspection of Blood Films vs Automated Analysis of Red Blood Cell Distribuition Width. Arch Intern Med; v. 148, p. 822-824, 1988.

SOUZA, A.M.; CAMARGO, M.B.; BACELLAR, D.T. L. CAMPOS, S.D.E.; FILHO, R.A.T.; ALENCAR, N.X. de; XAVIER, M.S.; MACIEIRA, D.B.; ALMOSNY, N.R.P. Valores dos Índices de Anisocitose (RDW-CV e RDW-SD) em Cães: Influência da Idade e do Sexo. R Bras Ci Vet; v.19, n. 2, p. 90-93, 2012.

WALTERS J. Hematology Review: RDW Measurements and Their Meaning. published by ACL Laboratories, Volume v. 3, n. 2, p. 2-3, 3rd Quarter, 2002.

WEISS, D.J.; TOWNSEND, E. Evaluation of reticulated platelets in dogs. Comp Haematol Int; v. 8, p. 166-170, 1998.

TEMIZEL, E.M.; CIHAN, H.; YILMAZ, Z.; AYTUG, N. Evaluation of erythrocyte and platelet indices in canine visceral leishmaniasis. Ankara Üniv Vet Fak Derg; v. 58, p.185-188, 2011.

ŽVORC, Z; RAFAJ, R.B.; KULEŠ, J.; MRLJAK, V. Erythrocyte and platelet indices in babesiosis of dogs. Vet Arhiv; v. 80, p. 259-267, 2010. 